\title{
The dean as an academic manager : the phantom of the opera?
}

Citation for published version (APA):

Paul, M. (2009). The dean as an academic manager : the phantom of the opera? Maastricht University. https://doi.org/10.26481/spe.20091127mp

Document status and date:

Published: 27/11/2009

DOI:

10.26481/spe.20091127mp

Document Version:

Publisher's PDF, also known as Version of record

\section{Please check the document version of this publication:}

- A submitted manuscript is the version of the article upon submission and before peer-review. There can be important differences between the submitted version and the official published version of record.

People interested in the research are advised to contact the author for the final version of the publication, or visit the DOI to the publisher's website.

- The final author version and the galley proof are versions of the publication after peer review.

- The final published version features the final layout of the paper including the volume, issue and page numbers.

Link to publication

\footnotetext{
General rights rights.

- You may freely distribute the URL identifying the publication in the public portal. please follow below link for the End User Agreement:

www.umlib.nl/taverne-license

Take down policy

If you believe that this document breaches copyright please contact us at:

repository@maastrichtuniversity.nl

providing details and we will investigate your claim.
}

Copyright and moral rights for the publications made accessible in the public portal are retained by the authors and/or other copyright owners and it is a condition of accessing publications that users recognise and abide by the legal requirements associated with these

- Users may download and print one copy of any publication from the public portal for the purpose of private study or research.

- You may not further distribute the material or use it for any profit-making activity or commercial gain

If the publication is distributed under the terms of Article $25 \mathrm{fa}$ of the Dutch Copyright Act, indicated by the "Taverne" license above, 
Oratiemp doc., 26-11-09

The dean as an academic manager - the phantom of the opera?

Oratie/Inaugural Lecture

27-11-2009

Final Public version

Prof. Dr. Martin Paul

Professor of Clinical Pharmacology and Toxicology

FHML/MUMC+

Maastricht University 
It is maybe somewhat unusual that a dean gives a formal inauguration lecture, but since the dean is a professor and since I came to Maastricht in this dual role one year ago, I find it most appropriate and to go through the same academic procedure as every new professor.

Many people have approached me with great expectations of this lecture, some asked me to give a grand vision of the strategic developments of the UM or the UMC over the next 10 years, others have even offered to provide slides or text pieces. I have answered them in a friendly way that this day and this lecture is not about the grand visions of the future, not about my research but rather simplistically about what I consider important at the core of an academic institution. And as a professor I should profess in what I believe.

The topic is academic management - to some, a contradiction in terms. Academic thinking based on scientific discourse, scholarship and creativity can certainly be stereotyped as being the antipode of the efficiency oriented management style of the business world. Like many stereotypes, this is wrong and I will make a case for the importance of the academic manager who has to play an important role in universities and university medical centers.

As indicated in the title, I will use the concepts and imagery of opera as an example to illustrate and define what is important to me in this context. This is not only because our academic traditions can sometimes have an operatic attitude but mainly because the art form opera has traditionally been used to comment on societal and 
political issues. And like operas inaugural lectures should not only convey a message, but also somehow entertain a diverse audience. In this context I have chosen to give this lecture in English, the second official language of our university so that also my guests from abroad can follow.

Opera has sometimes the air of the past, a bourgeois entertainment or an anachronism. Certainly, the uniqueness of opera as an integrative means of communication has today in part been taken over by modern media, but it should be pointed out that it is still one of the few art forms that integrate images and environments, story line and expression, texts, sounds and symbols in an unparalleled live experience. Opera is not only interesting in its interpretation but also reflecting on the social context of the audience with all its components. Historically, opera houses has often been used as a meeting ground and place for dialogue between different parts of society to interpret political views and their challenges, governance and social experience in a presumably neutral atmosphere. In short, opera has presented and still presents a publicly visible and politically usable communication area with important implications. Occasionally, opera performances can even initiate political unrest or even a revolution. One of the most famous examples of this (and obvious to be mentioned here) is the start of the Belgian revolution against the Dutch in the year 1830 leading to the secession of the southern provinces from the united kingdom of the Netherlands and ultimately to the foundation of the Belgian state. In this case a performance of Auber's presumably innocent opera La Muette de Portici (the mute woman of Portici) which was set during an uprising of Naples against the Spanish occupiers (interestingly presented as a special performance for the birthday of Dutch king Willem I) gave rise to a 
revolution. During the performance the duet "Amour sacré de la patrie" sparked the riots. Coincidence or oversight by the planners of this performance?

But for today I choose the opera world as a metaphor, not by entertaining you with music but using the operatic context to make my point. And, as in every opera, my presentation will be grouped in acts. So after this overture, let's start with the first act. It is entitled:

\section{Leading by learning}

As discussed earlier, opera speaks to us through images, words and music. And deliberately I chose the title of my lecture not because of flashiness, the image of the phantom can first be used to describe the special situation of a dean, since he or she is sometimes considered as a foreign body in typical management circles. Since deans are usually autodidactic learners in their management training and experience, they may not earn the trust of professional managers. On top of that the phantom relates not only to the role of the dean in general, the term has also some resemblance to my own situation. For many of you I came as a sort of phantom to Maastricht - certainly an experienced dean - but unknown to most of my new colleagues, Why, would many ask, did I move from the Charite in the German capital to the much smaller Maastricht, or - to use the image of opera houses - why moves an established performer from a well known opera house to a new company in up building, who is he, and what role will he play, prima ballerina or stagehand? I will give you some explanations in today's lecture and at the end of this session. 
But let us go back to the general characteristics of deanship and the title of the first act: leading by learning. This title reflects the origins and the typical management style of a good dean. He or she has learned his skills by own experiences and by watching others. The dean is chosen from the professors or in some places senior personnel of a faculty which is quite an unusual way to select a manager (but given the recent experiences with the economic crisis, probably also an interesting method for the business world). The dean, therefore can be characterized as a manager who a) has risen through the ranks and b) represents a person in middle management, meaning that he or she has to give leadership to a group of people and at the same time report to some sort of upper management.

Of course the roles of deans underwent many modifications and if anything the function of the dean today is a more complex, having developed from a mostly honorary appointee who has to represent and not manage. Recently, the role for the deans has been constantly growing into an executive function, leading to the phenomenon that more and more deans' position become full-time engagements characterized by growing tasks and independence. Nevertheless and because of this it is important that the dean never forgets his or her origins, never looses touch with the base and never turns into a pure technocrat.

The particular managerial role of the dean has been aptly defined by Jeffrey Buller in his standard book "The essential academic dean". He gives the following advice to the dean: "The method of interacting with department chairs, division directors and faculty members in your unit should be a reflection of the role you yourself wish to play in the larger institutional structure, in fact, you should treat others the same way, 
as you wish to be treated by the top of the university; this will help to shape your own role". According to Buller, the characteristic of the dean's interactions should be guided by "collegial candor". What does this mean? "First it requires creating a working environment in which individuals feel safe to provide their perspectives on various issues and understand that you will agree or disagree with these views according to the arguments merits, not according to the individual advancing it. Second, it requires fostering an environment where the overall mission of the institution, rather the personal convenience of its individual members, is the guiding principle behind all deliberations."

Indeed, this function from the middle ground as an intermediate between the academic base as well as the top governance provides a potentially difficult position but this difficulty can be overcome when applying the principle "leading by learning" which means that as leaders we need to learn and adapt not only from our experiences in growing up within the academic community, but also by learning from the examples of others who are now undergoing this process, like our students. I find it, for example refreshing and stimulating that students take an active part in our university. It contributes very much to an open atmosphere that the faculty council consists of $50 \%$ students and a student sits on the board of our medical center - a situation currently impossible in Germany and many other countries and a clear reflection of the Dutch polder model.

But how can opera help us to learn more about leadership styles and their consequences? The question of power, how to get it, how to use it and how to loose it is a key issue in many operas. Operas often deal with kings and other member of the ruling class and interpret how they govern; they discuss those who rise to power 
from simple beginnings to the top and then fail. The latter ones are of course the most interesting for our case study about the dean. Clearly we can recognize two different pathways determining the fate of those rising from the base. A large portion of those who go all the way to the top will at some point misuse their power, loose contact with their constituents and (at least in the operatic world) usually meet a violent end. The operatic literature is rich in such violent fates. Verdi's Simone Boccanegra, the first elected doge in Venice, is poisoned, Wagner's Rienzi, notably also the last of the tribunes, jumps into a fire and Don Giovanni is simply going to hell. In all cases this is related to some sort of managerial failure or a misunderstanding of social context or conventions. But there are also positive examples, such as Wagner's Parsifal, who starts out as a completely ignorant individual, but learns in Klingsor's Zaubergarten in a truly problem based way, salvages the Holy Grail and revitalizes and reinspires his dying community. In Parsifal, for me Wagner had a taste for too much pathos and there are more likable opera heroes such as Figaro who manages to reach his goals and at the same time interacts efficiently with his partners at all levels of his societal context. If I attempt to transfer this message to the dean's environment in today's universities, it does not certainly mean that the dean should become - in accordance with Figaro's famous aria from the barber of Seville - the factotum of the whole city - but indeed a true manager from the middle, who earns respect from the top university management and the base of the faculty alike. To be effective and respected this also means he or she should neither be a servant nor a dictator, a leader certainly, but a leader aware of the context, aware of the environment. Leading by learning to come back to the title of the first act means that listening, learning and leading based on the sensitivities of the professional context is the biggest asset of a good dean. 
Now, after we have defined the Dean's role and mission, let's examine the dean's context, and discuss governance and with this we can move to the second act entitled:

\section{The mountain and the valley}

In a country where a significant portion of the land lies below sea level one is fascinated with every elevation, and of course our region has rightly been nicknamed the Dutch alps, as indeed the highest mountain of this country, the Drielandenpunt is located here in Limburg, with 323 meters height an important landmark although we easily forget the fact that we share this peak with two other countries.

But for today's purpose the image of the mountain and the valley of course is used by me to reflect on the relation of the dean to the top of the university and its administration which in Maastricht most appropriately also literary sit on top of mountain (at least a mountain on the Dutch alpine scale). Fortunately, this mountain is not really high and the flat hierarchies in the Dutch academic system in comparison with the system where I come from are much appreciated. Nevertheless, our University deals with governance challenges that are ubiquitous in today's academia such as the distribution of tasks between the deans and the executive board of the university, the issue of centralization versus decentralization, efficient but academically sound management of projects portefeuilles, defining the vision of the university and its financial and strategic implications. Clearly, this is an area where conflicts are easily possible. In addition, a uniform assessment of this interaction is difficult to make since upper administrations of universities can differ. 
Some presidents have a relaxed attitude and are concentrating on fund raising and purely representative tasks within the governing board. They like to have their deans running their faculties quite independently and only want to be bothered with difficult problems. Others may want to know every detail of every faculty decision, even on the most insignificant detail level, and wish to be involved in every decentral decision. Good universities, like ours, integrate the deans and the executive board to form a joint management team, which should not be used as a nice decoration or window dressing, but actually the place where strategic planning and governance issues are discussed leading to decisions for the better good of the university.

What is the dean's position in this context? Again Buller's work on the academic role of deans gives important advice. The dean needs to rely on creating transparency and providing communication The dean is to keep the upper level of the university informed about what is going on in the faculty at the extent that they think it is necessary, even if that would not be the deans preference if the dean would be the president. A relationship based on transparency and communication will in every case make day to day work easier. Top level administrators of a university may not always understand the complexity of issues as they are also preoccupied with their own tasks. By not addressing the usual multiple dimensions of problems, they may pursue just one aspect without seeing the big picture, which then may harm the project as a whole. So communication and information is important and this is not to be confused with double governance. At the same time the dean should expect in return for this transparency the trust and confidence of the executive board of the university that he or she will take care of decentral issues and details along the lines of the outlined strategy and it should in exchange allow the dean to pursue important projects at the decentral level without to much disturbance. This process should lead 
to a general understanding of what is pursued on the central versus the decentral level within the university. It is important to have such a discussion in universities today, as the challenges that we face become more complex and diversified. Without doubt a clear distribution of portefeuilles which then also have to be respected, it is difficult to respond to this challenge adequately.

By creating an atmosphere of transparency and trust, a delegation of tasks from the center of the university to you as a dean and for your faculty will then be a natural consequence and help you in your managerial work.

To achieve this, the interaction with the president and the top of the university should e based on three main principles.

Honesty: Deans and members of the top leadership of an institution rely on sound information of each other. It is never good if deans read about new projects of the university board for his faculty in the newspaper and vice versa. If the leadership of an university is about to go in a dangerous or wrong direction it is the obligation of a dean to point to these potential problems. The worst deans are the yes deans who always concur with any decision just to preserve the atmosphere. They are equally damaging as those who always say no and block every new development. The yes people are of course more often the survivors since the no people will fast run into a permanent conflict and these are the deans that will retire soon. Meetings with the Yes deans with top of the university are quite pleasant and short but these deans fail in performing in their essential role as academic managers. It is our obligation to give the best possible advice to our superiors, even if that means not supporting a 
decision but pointing out a better alternative. As a dean the role should be that of a good advisor who helps the university to to do their jobs effectively.

Professionalism: Whenever there is disagreement with the superiors, the dean should communicate this in a professional and unemotional way. The advise should be focussed on content and not based on emotion and always include what can be considered as a better alternative. The dean should always treat his superiors in the same way as he you would like to be treated by the members of his own faculty. If there is disagreement with the president or the rector, the dean should, therefore, always make it clear that it is the decision or direction, with which there is disagreement, not the person. An atmosphere of collegiality built up between top and middle management will be most helpful to guarantee this

Confidentiality and loyalty: Although this may be bad news for the local university newspaper who heavily relies on gossip and informal information, it is important that candid and sometimes controversial discussions can be carried out behind closed doors without leakage of potential conflicts to the outside, as this can be quite damaging to an institution. It is the result that counts and that should be communicated to the public not the potential struggle to reach a consensus. There will be also situations where the dean has done his best to convince the management partners that they do something that the dean may consider wrong and in the end is overruled. In this case the dean has to act professionally in such situations and be loyal his colleagues. Such loyalty does not mean that academic managers should compromise their principles but it means that conflict in a board should be carried out in board meetings and not in the public. If decisions are taken 
that are not entirely on his line, the dean should support what can be supported without bending over backwards.

From these comments it becomes clear that the dean sometimes has to steer a difficult course when dealing with governance issues within the university.

By following the guidelines defined above (honesty, professionalism and loyalty) the dean regularly can achieve the best possible outcome for the faculty, and influencing the university policy as a whole.

How can opera help us in this context? Mountains and valleys are certainly used as backdrops in many operas. These geographical locations can produce challenges for the designer of operas sets which may lead to disappearance of operas from the repertoire such as Catalanis La Wally, where the third act has to be played out on a mountain top in the Austrian alps or Donizetti's Linda die Chamonix where a team of climbers does not make it to the top of the Mont Blanc. Other opera's use mountains and valleys to illustrate societal imbalance such as the opera TIEFLAND, "the low country" by Eugene dÁlbert, which surprisingly does not play in the Netherlands but rather in the mountains and plains of Navarra.

When it comes, however, to mountains and valleys as images for governance, there is clearly one opera or should we say set of operas that comes to mind, Richard Wagner's "Der Ring des Nibelungen". Not only are the gods situated on top of a "berg", a mountain named Walhalla, a large portion of the tragic endplay and of the failing dialogue of those on the top with their people, localized in this instance not at the banks of the Maas but in the Rhine valley, leading to general disaster most 
appropriately termed in the last piece of the trilogy, the twilight of the gods. It would do injustice to summarize such a multidimensional work as Wagner's masterpiece in a chapter of an inaugural lecture - one could certainly spend days talking about this - but besides many other themes relevant for society, the disaster unfolding in der Ring des Nibelungen certainly can be used as a bad practise example of misunderstood leadership, bad governance, disrespect of borders and intransparent communication.

The third act is entitled

\section{$\underline{\text { Capriccio }}$}

and is not reflecting on the musical style defined by this term, but rather on Richard Strauss last opera. Capriccio is an opera about the opera, a conversation piece addressing opera itself and the question of what is it's most important feature, music or words. "Prima la musica, piu la parole", first music and then words is the famous statement made in this opera and I will use this to discuss the dean as an academic manager within the boundaries of a university medical center.

In a university medical center, the dean has a dilemma as he is usually moved out of a position of middle management into a top management position as the integrated university medical center is usually governed by a board including the dean. This can create a sort of double role as the dean is on one hand embedded in the university below the upper administration but in the medical center clearly in the top line. This unique situation can generate friction but a good dean can manage very well 
between the two worlds, if he follows a line of mutual enhancement, not inhibition and adheres to the same managerial principles lied out I in the first part of my talk.

University medical centers and their medical and health science faculties can sometimes be big and scary to other faculties, as one of my colleagues said they can create an image of an elephant versus a mouse, That's why the dean representing health, medicine and life sciences will have to play a role as a moderator and ambassador for his fields at the university side. At the same time he or she truly has to represent academia in the hospital. Here the dean faces another dilemma: whose interests come first on this side of the set: The question asked in the Richard Strauss piece: how can we assess what would be the best opera and what would be the leading principle for such a musical piece - music or the libretto can be translated to the world of academic hospitals and university medical centers accordingly. What is the leading denominator for such a center: academic medicine or efficient patient care at good value?

Of course both aspects are of utmost importance. Just having an academic playground without attention for the needs of our patient and their budgetary consequences, we will run into sure disaster, strategically and financially. On the other hand, if we make the mistake to try to be just another good hospital, we as university medical centers will most likely fail, because due to our role in education and training it will be very hard if not impossible for us to compete with those streamlined peripheral hospitals which generate high throughput care without the additional burden we have to carry. Our critics will usually say, that academic principles cannot guide such an operation since it the end we talking about budgetary streamlining and a financially, sound operation and not 
expensive academic tasks. They have a point and without any doubt the academic hospital must also have a healthy economic structure. But this does not mean that we have to give up our academic principles.

First the music and then the words does of course just give an order of priorities, it does not imply that one of the two components can make it on its own. But how do we provide an integrated basis for successful operation of an academic health center? As I said at the beginning, operas are a multimedia experience, they depend on a good libretto, the set, the orchestras and the singers among others and with just having leading tenors and primadonnas the cannot put a good piece on stage. They heavily depend on the cooperation of the chorus, the corps de ballet, and yes - the stagehands. People with very different talents and backgrounds working together to present a good integrated work - that is what we also need in our University medical centers, but we need to convince them of our common mission and goals. To achieve this, the dean will have to work integrally together with his colleagues on the management board of the Medical center. The basis of their collaboration again will be trust and respect for each other.

The academic commitment should of course be no hindrance for us to play nonacademic roles in the community such as delivering second line health care to the region if they are following an academic Leitmotiv. Academic medicine does not automatically imply that it has to deal only with rare, complicated and expensive diseases. For example, a lot of my own research has been focussing on hypertension, a very common disease, easy to be diagnosed and with good therapeutic tools, certainly not belonging to the spectrum of third line care, yet scientifically highly interesting. Research on such simple, inexpensive diseases 
can easily be part of the top academic spectrum of a university medical center as in the end the mix of subjects is important which makes such an operation also financially sound.

Academic medicine should, therefore, not be stereotyped as simply being expensive and tertiary care related, no academic medicine is defining itself be the scientific character of the questions it asks and the answers it can give. The common denominator must be quality and excellence, not only in research but also in education both for our students and the young physicians. The latter is often forgotten and I am proud to be at an institution where learning excellence is so important.

But we have to be aware that university medical centers face financial challenges. All hospitals, academic or not, have to be financially viable as I said previously. The introduction of DRGs - in the Netherlands they are called DBCs- , the unrest about the ongoing financial crisis and its implications for the health care sector certainly have led to financial pressure on university medical centers, and they have to respond. Just cutting costs across the board without sensibility for academic tasks will in my view be a wrong reaction. In contrast, the academic profile (in education, research and patient care) should be an important parameter when we have to make crucial financial decisions and even cuts to realign our strategy. As I said before, we must strive for an optimal combination of high quality health care with academic excellence in education and research which is of utmost importance in a time where we have increasingly to deal with competitors on the local and regional hospital market. Our centers must combine a certain academic light tower function in defined areas while at the same time 
provide excellent medical care and education across the board. That can mean that even the focus on an academic segment that on first view appears to be expensive, maybe because the patient base is too small or the diagnostic procedures are too costly can ultimately be a winner for the university medical center, because it generates visibility within the public and will attract patients also without less rare and complex diseases, which generate a good income for the hospital. Academic hospitals and university medical centers have to respond to the challenges of an ever tightly financed health market by differentiation. Running an excellent university medical center, therefore, means to make choices, choices for the spectrum and in the definition of focus areas where patient care research and basal as well as continuing education play integrally together. The Maastricht model of focus and care chains provide an excellent basis for such a strategy which now has to be developed further and translated into the future. If you consequently follow up on this groundwork and use it at a basis for redefinition of our UMC for the future under the guidance of academic principles, even times of financial hardship can turn into an area of strengthening, in brief, the crisis must always considered as an opportunity.

Maastricht has another important strength - the integration of the formerly independent faculty of health sciences and its life science programs, most inappropriately summarized in the small plus sign found in our provisoric logo. The health continuum spanning from prevention, early diagnosis, optimal, evidence based treatment but also rehabilitation and societal impact, can integrally be studied and communicated to our students and the motto from cell to individuals to society can be considered as a true asset to deal with the multidisciplinary challenges of the health market. 
But we also have to look outside our own little world. With this I mean networks of academic medical centers on a nationwide scale but also regional networks. First the partnership with other university medical centers to coordinate their integral strategies, provide a strong academic lobby and lays the groundwork for research and education activities within our spectrum. This has been done in the Netherlands in a remarkably efficient way with the creation of the NFU, the Dutch federation of university medical centers in an exemplary fashion. At a recent conference in Washington the Dutch model has been defined as the most advanced model and best practice of creating efficient academic health centers and possibly as a result of this advantage, the Dutch University Medical Centers score very highly internationally. It is remarkable to note that 5 out of the 8 university medical centers rank among the top 20 in the times higher education research ranking of academic medical centers in Europe, whereas much bigger countries such as Germany, France and Italy who also have a strong history in academic medicine are scarcely present on the list. It is interesting to discuss why this is the case. In my view the early integration of strategies between all branches that are academically important, patient care, research and education in the Netherlands are a basis for this success.

The second important network that must be formed is a network with our regional partners, These may be hospitals in the same city or state which whom we share responsibility not only for patients but also education and training and which also can be valuable partner for research. Or they may be ambulatory care networks with an academia oriented focus. It goes without saying, that in Maastricht we have to turn our regional disadvantage in the Netherlands being in a sort of 
appendix of the country where we share more borders with our neighbouring countries than contact with the homeland into an advantage by strengthening our relations with neighbouring institutions across the boarders and particularly in the Euregion (Aachen and Jülich, Luik and Hasselt, Eindhoven and Leuven are important partners for us). The fact that Maastricht University is the most international university not only in this country but also in Europe and that the University Medical Center and the University explores the creation of bigger international networks across the traditional boarders must be considered as milestone in the further development of our academic mission.

To come back to the image of opera what comes first in this process music or words - we can translate this to our world to the question of the primary role within a University Medical Center, namely the preordination of patient care versus the unity of education and research, the answer is clear. In the same way as opera without the leading theme of music is not an opera at the same time is a university medical center without the guidance of academic principles just another hospital, a hospital which is left alone to find its competition without academic mission and protection. This is by the way no matter of conflict - to the contrary. Strauss opera ends with the statement of its main character, the countess, that in the end both, the librettist and the composer have to work together in an integral way to generate the opera as a Gesamtkunstwerk. The role of the dean in the board of a university medical center is correspondingly to act as a guarantor of such integration. He or she must stand for the academic principles of the forming and operation of academic medical centers yet within an integrative management board also is able not only to understand, but also to influence patient care structures. 
But does this not threaten the interaction with the university? This of course can be the basis of conflict, but should be considered as an opportunity. As academic institution we are dealing with an increased complexity of tasks. Networking between faculties, for example in the development of new education programs or in the generation of innovative research initiatives and networks is increasingly desirable and necessary. Therefore the policies of the University medical center should be well coordinated with the university strategy as a whole to guarantee that the academic health center (while having a different governance structure) remains a part of the university family. Again the dean must not only be the link between the two institutions but also the mutual translator between what still can be considered as different worlds.

I come to the last part of my lecture, which has dealt with three issues of the role of the dean as an academic manager

1) The dean's style of management

2) The dean's role in university governance

3) The particular role a dean has to play in the management of university medical centers

This short list makes it clear that the dean must be a manager at many interfaces and with a complex array of tasks. The multitude of roles to play, the integration of academic spirit and thinking with down to earth management also makes the attractiveness of this position. 
That is why I felt it more important to talk about the role of the dean itself and that what I consider as the core of our academic business. The dean may be a phantom, since he or she is not brought up in management school rather a person whose talents were discovered by his or her peers. Nevertheless the dean is a factor for which one has to account for. With the increasing diversification and specialization of universities and university medical center deans and other academic managers will play an essential role to steer and get our academic jobs done. They do so with a much closer relation with their base from which they grew into their management position to get their job done.

So in the end, my message to you is a simple one. A good dean never forgets the academic core of the business and his or her role within this context. As I have said earlier, deans should never forget their own upbringing within the system starting as a student; he or she should learn from his environment and integrate these experiences in the application of his tasks and should always apply the principle of management from the middle. The role is that of a coordinator, a moderator and strategic leader. In the end the opposite of a phantom and in the end certainly not a member of the performing cast and certainly no primballerina or heldentenor. These roles should be played by our professors, our co-workers and our students. The dean, in contrast, has a role which corresponds more to that of an impresario a set designer, a producer or even sometimes conductor. He or she stands very often behind the scenes. In this sense our main work is done before the performance starts and when the show is over, the curtain has fallen. Of course then begins our job begins from anew as have to give our immediate attention to the next production. 
Like in Wagner's ring another important story line of my lecture has been governance. And indeed my personal most favourite opera - apart from being a musical masterpiece - also deals with the best practise of governance.

It is: La Clemenzia di Tito, Mozart's last composed opera. Tito, based on the historical figure of the roman emperor Titus, is on one hand certainly not a part of middle management. But on the other hand he shows many characteristics of a good manager. Having vision, yet listening to his constituents, adapting decisions based on good advice and using a governance style based on communication and transparency. Good governance is always dependent on those who are governed, that are a central message in Mozart's work and certainly a motto for efficient academic governance. To help achieve this in an exciting environment where I see high potential for further development, which was one of the main reasons to move from the German capital to this exiting region in the heart of Europe. And I hope that after 15 months of working together, I am no longer considered a phantom. 